\title{
Einwirkung von Grignard'schem Reagenz auf 1-Acetyl-2-methylindolizin.
}

\author{
von \\ Heisaburo Kovido u. Shunsaburo Osawa \\ [Aus d. pharm. Inst. d. Univ Tokyo] \\ (Eingeganzen am I. Juni 1936)
}

Tschitschibabin u. Stepanow (B. 62, 1070) erhielten bei der Einwirkung von Aethylmagnesiumbromid auf 1-Acetyl-2-methylindolizin eine Verbindung vom Sdp.9 $95^{\circ}$ u. Smp. $59-60^{\circ}$, die sie durch die Stickstoffbestimmung als 1-Aethyl-2-methylindolizin annahmen.

Bei der Nachprüfung dieser Reaktion erhielten die Verfässer ebenso eine krystallinische Verbindung vom Smp. 59.5 ${ }^{\circ}$, die sie durch die Analyse und durch die Mischprobe als 2-Methylindolizin erwiesen. Der direkte Vergleich ihres Acetylderivates mit dem 1-Acetyl-2-methylindolizin zeigte die Identität beider Verbindungen. Die literarische Angabe über den Schmelzpunkt vom 2-Methylindolizin muß daher statt $68^{\circ}$ als $59.5^{\circ}$ korrigiert werden. Den Verlauf dieser Reaktion kann man also wie Folgendes verstehen.

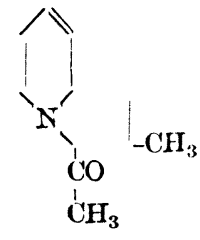

$$
+\mathrm{C}_{2} \mathrm{H}_{5} \mathrm{MgBBr}=
$$

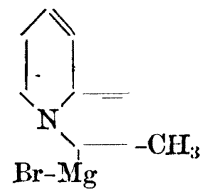

$$
+\mathrm{CH}_{3} \mathrm{CO} \cdot \mathrm{C}_{2} \mathrm{H}_{5}
$$

Um diese Vermutung sicher zu stellen haben die Verfässer aus dem ätherischen Destillat des Reaktionsproduktes Methyläthylketon als sein p-Nitrophenylhydrazon vom Smp. $128-29^{\circ}$ nachgewiesen.

Es ergibt sich daher eine Möglichkeit einer neuen Methode zur Synthese von einer Reihe der 1-substituierten Indolizin derivaten, wenn man gleich nach der Reaktion. vom Alkylmagnesiumbromid ein zweites Halogenalkyl bżw. Halogenacyl einwirken. lasse.

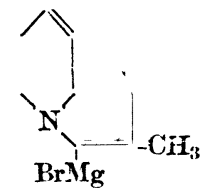

$$
+\mathrm{R}-\mathrm{X}=
$$<smiles>[R]C1=C(C)C=[IH]2CCC=CCN12</smiles><smiles></smiles> 
Die Bestätigung dafür ist noch nicht vollendet.

Beschreibung der Versuche.

Einwirkung von Aethylmagnesiumbromid auf 1-Acetyl-2-methylindolizin. Krystall vom Smp. 59.5 :

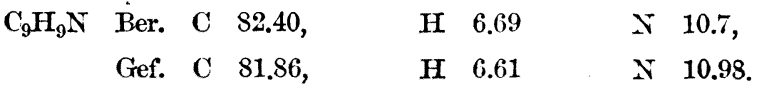

(Autorenref.)

\title{
Über die Bestimmung des Wismuts mit Antipyrinmethylenamin
}

\author{
von
}

Seisi Takagi und Yuzo Nagase

[Aus dem pharmaceutischen Institute der Kaiserl. Universität Tokio]

(Eingangen am 5. Mai 1936)

Es gibt in der Literatur ${ }^{1)}$ einige Methcden, wonach man Wismut als Tetrajodobismutisaures Salz organischer Basen fällt und bestimmt. Verff. haben Antipyrinmethylenamin ${ }^{2)}$ als organische Base verwendet und gute Resultate mit gewichtsanalytischen Versuchen erzielt. Da diese Base aus Antipyrin und Urotropin leicht hergestellt werden kann, ist es ein billiges und leicht zugängliches Reagens.

Versetzt man die essigsaure Lösung eines Wismutsalzes mit Kaliumjodidlösung und fügt nach der Bildung von $\mathrm{HBiJ}_{4}$ die gesättigte alkoholische Lösung der oben erwähnten Base hinzu, so entsteht ein voluminöser, gelbbräuner Niederschlag, der durch Erhitzen im kochenden Wassarbade in einen schön rotbraunen, etwas schweren Niederschlag übergeht. Die Erfassungsgrenze dieser Reaktion beträgt $0,000005 \mathrm{~g} \mathrm{Bi}$ in $1 \mathrm{ccm} \mathrm{d}$. h. die Grenzkonzentration ist $1: 200000$.

Diese Reaktion lässt sich durch Tüpfelreaktion auf Filtrierpapier in folgender Weise ausführen. Man bringt 1 Tropfen der schwach sauren Probelösung auf Filtrierpapier und darauf wird 1 Tropfen einer Mischung, die aus Kaliumjodid und oben erwähntem organischen Reagens besteht, aufgetragen und durch Erhitzen und Trocknen über einer kleine Flamme entsteht bei Gegenwart von Wismut ein roter Fleck. Erfassungsgrenze : $0,2 \gamma \mathrm{Bi}$. Grenzkonzentration ist $1: 250000$. 


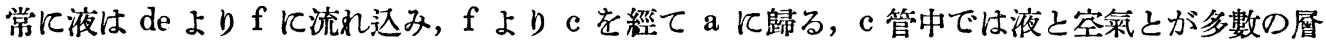
を作り上昇し，斷へず 2 液は循環する。

てのポムプは液の循環量が少ない，また時として數秒間流下が止るととがある，が使朋に耐 へない樣なものではない，圖中に舉げてある液の標高寸法は最良の場合を示したものではない， 管の內徑寸法にしても同樣である。

な瓜 b 管が $f$ の下をまわつてねるが，てれは何等かの故障の場合に液が逆流するととを妨 ぐ䉆めであつて，必要なととである.

全部硝子製であるために强酸强アルカリが使用出來るが，此較的多量の空氣に接觸するのが 1 つの缺點と云へる.

\section{利尿生藥の成分㗏究（第二報） \\ ドクダミのフラヴォノール配糖體に就て}

$\begin{array}{llll}\text { 中 村 晴 } & \text { 吉 } \\ \text { 太 } & \text { 田 達 } & \text { 男 } \\ \text { 稫 地 } & \text { 一 } & \text { 一 郎 }\end{array}$

（三共株式會社研究課）

（昭和 11 年 5 月 10 日受理）

H. Nakamura, T. Ohta und G. Hukuti : Über das Flavonolglycosid von Honttuynia cordata Thunb. (Untersuchungen über die

Bestandteile von diure'ischen Drogen II.)

ドクダミ（重綝，藏藥）Houttuynia cordata Thunb. は古來加ら主に利尿藥として廣く民閂 に用ひられて居る。この利尿成分に付ては現在に至るまで何等の研究報告がない，吾々はての 成分が Flavonglycosid て基因するもであるとの見解で研究した所，豫期の通り一種の Flaronglycosid を捕捉した.

本物質は $50 \%$ Alkohol から精製すると带色細針晶となり Fp. 182-5 . 2 分子の結晶水を含 み, 分析數は $\mathrm{C}_{21} \mathrm{H}_{20} \mathrm{O}_{11}$ に一致する。乙れを稀硫酸で煮沸すると Aglycon として Quercetin

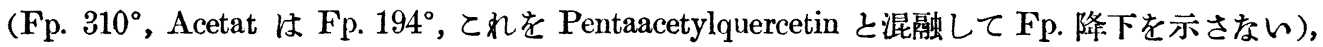

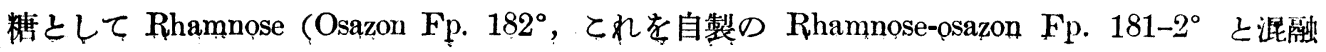


して Fp. 降下を來さない）に分解する. Quercetin の定量の結果は Monoglycosid に一致する. 故に加水分解式は次の如く示される。

$$
\mathrm{C}_{21} \mathrm{H}_{20} \mathrm{O}_{11}+\mathrm{H}_{2} \mathrm{O}=\mathrm{C}_{15} \mathrm{H}_{10} \mathrm{O}_{7}+\mathrm{C}_{6} \mathrm{H}_{12} \mathrm{O}_{5}
$$

次に配糖體を Diazomethan で充分メチール化した後，てれを稀硫酸で分解して得た Aglycon

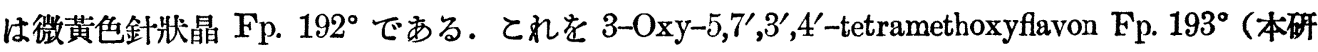
究第一報の Isoquercitrin から誘導して得たもの）と混融して降下を來さないので，從つて原配 糖の糖の位置は “3”位である。即ち吾くがドクダミから得た Flavonolglycosid は Quercetin3-rhamrosid (Quercitrin) として性狀交獻記载に良く一致する. (Quercitrin の Fp. は Perkin, Everest (The Natural colouring matters [1918]) によれば Fp. 182-5であるが Wester (Rec. Trav. Chim. Pays-Bas, 40, 707 [1921], C, 1928, I. 709) は Perkin 等の與へた Fp. は高 すぎる，Fp. 174-6 $6^{\circ}$ であるとの報告がある).

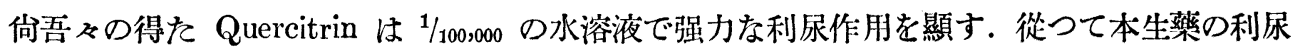
成分と考へられる。

本研究は恩師朝比奈教授の御懇篤な御指導を得た。謹で深謝の意を表する.

\section{實 驗 之 部}

配糖體の抽出及性狀

市販品のドクダミを細切して,メタうールで椧時反復振盪して浸液を蒸溜浱縮し，更に減壓 でェキスとしたものを溫湯で浸出する．澄明に滤別した浸液を $\mathrm{CHCl}_{3}$ で振盪しててれに移 行するものを除去した後, 醋酸エステルで充分振取する. 醋酸 エステルを蒸溜濃厚 とすれば Flavonglycosid を析出する. 粗物質の得量は生藥の約 $0.5 \%$.

50\% Alkohol から再結晶すれば淡黉色細針晶となる. Fp. 182-5 (分解). Alkohol 溶液で $\mathrm{FeCl}_{3}$ 液によつて暗綠色となり $\mathrm{Mg}+\mathrm{HCl}$ で紫赤色を呈する. 冷水, Alkohol に難溶, 熱 $\mathrm{Al}$ kohol には可溶.

元素分析

物 質： $0.0316 \mathrm{~g}$ (結晶水含有) $\mathrm{CO}_{2}=0.0598 \mathrm{~g} . \mathrm{H}_{2} \mathrm{O}=0.0133 \mathrm{~g}$, Gef. $\mathrm{C} \%=51.63, \mathrm{H} \%=4.71$ Ber. $\left[\mathrm{C}_{21} \mathrm{H}_{20} \mathrm{O}_{11} \cdot 2 \mathrm{H}_{2} \mathrm{O}\right],=52.07, ”=4.95$

結晶水の定量 物 質: $0.2180 \mathrm{~g}$, ネ $125-130^{\circ}$ で恒量まで乾懆した 減量 $=0.0160 \mathrm{~g}$ Gef. $\mathrm{H}_{2} \mathrm{O} \%=7.33$ Ber. $\left[\mathrm{C}_{21} \mathrm{H}_{20} \mathrm{O}_{11} \cdot 2 \mathrm{H}_{2} \mathrm{O}\right] ”=7.43$

\section{配糖體の加水分解}

Aglycon の證明

物質を $5 \%$ 硫酸と共に加熱すれば一旦溶解して暫時の後黃色物質を析出する. 約 2 時間後, 冷却, 吸引滤過, 水洗する. てれを稀 Alkohol から 1 包再結晶したものは Fp. $310^{\circ}$ の黄色 
結晶. この Aglycon を Essigsäureanhydrid と 浱硫酸でアセチール化して 1 回 Alkohol から再結晶したものは無色針狀晶 Fp. 194。.てれをPenta-acetylquercetin と混融して Fp. 降 下を示さない.

\section{糖の證明}

Quercetin を滤別した液及洗液を合佭して $\mathrm{BaCO}_{3}$ で中和し, 滤過, 瀑縮して Sirup とする. てれを更に Alkohol で抽出して Alkohol 蒸溜殘渣 (Aceton-HCl に上る Methylpentose 反應 顯著である) を多量の水に溶解して HCl-Phenylhydrazin, 醋酸ソーダを加へて水浴上に加熱す る. 生成した黄色針晶を吸滤, 水洗, 乾燥する, てれを Aceton に溶解（全溶する）して更に 水を加へて析出したものを Alkohol から再絬晶したものは Fp. 182 . てれを自製の Rhamnosephenylosazon と混融して降下しない。

\section{Aglycon の定量}

配糖體 (無水物) $0.8883 \mathrm{~g}$. を $50 \mathrm{cc}$ の $5 \% \mathrm{H}_{2} \mathrm{SO}_{4}$ で水浴上に 1 時間加水分解を行ふ. 1 夜 水室中に放置後析出したQuercetin を Goo.h 坩堝に取り乾燥, 科量したものは 0.5936 g. Gef. Quercetin $\%=66.82$, Ber, $\left[\mathrm{C}_{21} \mathrm{H}_{20} \mathrm{O}_{11}\right]=67.41$.

\section{糖の位置の決定}

配糖體 $0.35 \mathrm{~g}$ をメタノール $15 \mathrm{cc}$ に溶解 (加溫) して, これに Nitrosomethylurethan か ら發生させた Diazomethan の Ather 溶液を反復通じて $\mathrm{FeCl}_{3}$ 反應の殆ど消失するまでメチー ル化する. 溶媒を溜去しててれを直ちに稀 $\mathrm{H}_{2} \mathrm{SO}_{4}$ で水浴上に約 1 時間加水分解する・冷後, 吸滤, 水洗, 乾燥したものは $0.24 \mathrm{~g} .50 \%$ Alkohol から 2 包再絬晶したものは微黃色針狀晶

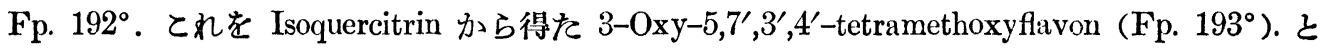
混融して全く Fp. 降下を生じなん. 